\title{
20. The Retiring Premiers: A New Style of Leadership Transition
}

\section{Paul Strangio}

'I will never resign. They will have to carry me out with my boots on' (cited in Knight 2003: 244).

Ned Hanlon, Premier of Queensland, 7 March 1946 - 15 January 1952 (died in office)

'I feel I could be premier for 20 years. Ha! Hubris - when we imagine we're gods. In my business you can be wiped out by events, and within a 24 hours news cycle'

(cited in Smith 2006: 496).

Diary entry early 2000, Bob Carr, Premier of New South Wales, 4 April 1995 - 3 August 2005

(resigned)

\section{Leaders who do know when to go}

In the introduction to their 2005 edited volume Yes, Premier: Labor leadership in Australia's states and territories, John Wanna and Paul Williams point to the 'surprisingly sparse' scholarly literature on sub-national politics in Australia and an associated absence of a 'systematic analysis of state leaders' (pp 25 and 29). The Wanna and Williams study was an admirable attempt to redress that latter omission through a collective study of the (then) current batch of sub-national leaders (all of whom, for the first time since Federation, were from the Labor side of politics). The publication of Yes, Premier was preceded by the third edition of The Premiers of Queensland (Murphy et al. 2003) and has been followed subsequently by collections of biographical essays on the premiers of New South Wales (Clune and Turner 2006) and Victoria (Strangio and Costar 2006). It would be wrong to exaggerate this trend. The famine has not turned into feast - state politics is still the poor cousin of national politics in the attention it receives from scholars, including biographers. Nevertheless, the output of the last few years has afforded an opportunity to augment our understanding of the patterns, both historical and contemporary, of political leadership at the sub-national level.

In the concluding chapter of Yes, Premier, Wanna and Williams, joined by Brian Head, isolated such patterns for the purposes of constructing an identikit of the contemporary sub-national leader. They suggest that the features of this 
archetype are: adaptation to the accountability regimes that have proliferated since the 1980s; 'professional perspectives' which include an interest in national agendas (as opposed to old-style state parochialism); 'resourceful and ubiquitous communicators'; 'transcendence over their section base', particularly trade unions; 'cautious pragmatism'; 'anticipatory and receptive leadership'; the employment of 'participatory and community engagement techniques' such as summits, community cabinet meetings and consultative/advisory committees; and, finally, 'ordinary populism' (Head, Wanna and Williams 2005: 261-3), which manifests in a leadership style that is

purposely non-elitist, a little mundane, attempting to be 'everyman' or 'everywoman' ... They are not classically charismatic; instead, they have a natural common touch. They have cultivated the image of the normal, ordinary, relaxed, accepted leader attuned to his/her community (Head, Wanna and Williams 2005: 258).

The same authors (Head, Wanna and Williams 2005: 263; Wanna and Williams 2005: 18) distinguish this leadership style from that which prevailed in the post-war decades during the age of the so-called 'boss' premiers (leaders such as Henry Bolte in Victoria, Thomas Playford in South Australia, Joh Bjelke-Petersen in Queensland, Charles Court in Western Australia and Eric Reece in Tasmania). They too were populists but of a rough hewn variety, their homespun folksiness mingled with a powerful streak of authoritarianism. By way of comparison, Labor's 'ordinary populists' might also be contrasted with their more immediate predecessors: the earnest technocratic modernists exemplified by John Cain Jnr (Strangio 2006) and Wayne Goss (Wanna 2003).

Since the publication of Yes, Premier, there have been elections in each state and territory, but Labor's stranglehold over government at the sub-national level has been maintained. Yet, the leadership landscape has been transformed. While the editors (Wanna and Williams 2005: 15) had speculated that 'many of these leaders will be around for some time - because of their perceived dominance', there has been a changing of the guard in five of the eight jurisdictions. Bob Carr resigned in July 2005 (replaced by Morris Iemma), Geoff Gallop resigned in January 2006 (replaced by Alan Carpenter), Steve Bracks resigned in July 2007 (replaced by John Brumby), Peter Beattie resigned in September 2007 (replaced by Anna Bligh) and Claire Martin resigned in November 2007 (replaced by Paul Henderson). While Gallop resigned because of illness, it has, nonetheless, been a striking sequence: the era of the retiring premiers. At one level, it invites the question of whether the age of the 'ordinary populist' is already passing. Of the premiers and chief ministers discussed in Yes, Premier, none better fitted the bill of the congenial, 'everyman' than Bracks and Beattie. Their respective successors, Brumby and Bligh, on the other hand, are of more combative style. 
The chief focus of this chapter, however, is on another question: whether timely departure is another trait of contemporary sub-national leadership and a further point of distinction from the 'boss' premiers of the post-war era. If so, what does this suggest about the evolving practices and demands of the office itself? Is it a trend also related to the changed career trajectories of those who rise to occupy high political office? The chapter also contrasts the recent rash of leadership successions at the sub-national level with former Prime Minister John Howard's model of clinging to office to the bitter end. Howard's failure to allow an orderly leadership transition is widely regarded as having been a major factor in the Coalition's election loss of November 2007 and the disorientation suffered by the non-Labor parties since that defeat. Will the example of what has occurred in the state sphere and the disaster that befell Howard and the Coalition in 2007 create an irresistible future impetus for timely departures and planned transitions at the federal level? Finally, the chapter concludes by asking questions about the knock-on effects leadership transitions; in other words, how much is actually transformed within the government that the departing leader leaves behind?

\section{'They will have to carry me out with my boots on'}

As exemplified by Ned Hanlon's stubborn response to advice that he relinquish the Queensland premiership due to failing health, timely resignations have not been a common feature of state (or federal) politics. Indeed, one is hard pressed to find examples of successful leadership transitions in Australian politics. Henry Bolte's passing of the baton to Rupert Hamer in Victoria in 1972 is an exception (Abjorensen 2007: 97). Hamer went on to extend the Liberal Party's hegemony over Spring Street politics for nearly another decade and along the way secured three election victories, the first two of which bettered anything achieved by his predecessor (Hannan 1979: 8 and 14-15). Yet, as elaborated below, there is a case to be made that Bolte had stayed too long — something he seemed to grudgingly admit upon resigning: 'Victorian politics will probably improve when I'm gone; get rid of some of the rough edges' (cited in Wright 1992: 205). In New South Wales there was, ostensibly, a sequence of successful transitions during Labor's two-and-a-half-decade unbroken ascendancy between 1941 and 1966 that encompassed the premierships of William McKell, James McGirr, John Cahill, Robert Heffron and John Renshaw. Yet, David Clune and Ken Turner (2006: 10-11) argue this was, in fact, illusionary: 'In none of these cases was it [the transfer of leadership] the result of a carefully planned transition'. Further, writing from a historical perspective, they believe that smooth transitions from successful leaders 'are almost contradictory as a successful premier by definition dominates his government and era and leaves a huge gap to fill'.

The collective record of the 'boss' premiers suggests a predilection not only for clinging to office too long, but of their leaderships taking on a darker, increasingly wilful edge with advancing years. Think, for instance, of Bolte's 
obduracy over the hanging of Ronald Ryan in 1967. As Mike Richard's compelling study The Hanged Man (2002: especially 394-5) convincingly shows, Bolte transformed the issue of the execution of Ryan into a test of his authority: he would not budge in spite of the diverse voices of protest in the community, intense opposition from the major metropolitan press outlets, disquiet within his own cabinet and the consternation of the legal fraternity.

In the same year that Ryan went to the gallows, Tasmanian premier Eric Reece revoked Lake Pedder's status as a National Park as a preliminary to its damming and submergence as part of the Upper Gordon Hydro Electric Scheme. In his second and final term as premier (1972-75), 'Electric Eric', by then in his mid-60s, obstinately proceeded with the flooding, staring down the protests of the burgeoning environment movement and spurning a generous financial offer by Labor Prime Minister Gough Whitlam to preserve Lake Pedder (Bolton 1992: 162-3; Whitlam 1985: 525-30).

Another example is Sir Thomas Playford jnr, whose record breaking 27-year premiership is unlikely to be ever matched. In the phrase of his biographer, a 'benevolent despot', Playford's incapacity to adapt to a changing social and cultural milieu in the 1960s and 'fantasy of indispensability' (he refused to relinquish the reins of government despite his extreme longevity of office and approaching seventieth birthday), ultimately and inevitability resulted in election defeat in 1965 (Cockburn 1991; Blewett and Jaensch 1971: ch. 2).

Then there is the one to trump them all, the 'populist autocrat', Joh Bjelke-Petersen. Following his seventh consecutive election victory in 1986, the septuagenarian Bjelke-Peterson succumbed to a kind of manic grandiosity that climaxed in the delusory and self-destructive 'Joh for $\mathrm{PM}^{\prime}$ campaign (Walter 2003: especially 317-21) which paved the way not for his conquest of Canberra but for his political demise in Queensland.

When surveying these records it is difficult to avoid the conclusion of a direct casual relationship existing between the ageing of the 'boss' premiers and the inflexibility of their later leadership. They were sufferers of the political equivalent of hardening of the arteries. Judith Brett (2007: 10), reflecting upon the predicament of another ageing leader — John Howard in 2007 — might well have been referring to the fate of the boss premiers when she described the hazard for elderly leaders of 'their inevitable disconnection from the social and cultural worlds of people born 20, 30, 40 and even 50 years after them - and from their futures'. Similarly, Angus McIntyre's edited study Ageing and Political Leadership (1988) provides a useful conceptual framework for understanding the trajectory of the ageing boss premiers. One of the typologies of ageing outlined by McIntyre, and which he suggests is the most common in politics, is what he terms 'manic ageing'. In essence, this is a denial of the reality of ageing, that is, 'a denial of death', which can manifest in 'a fantasy of immortality or, 
at the very least, indispensability' (Macintyre 1988: 282-6 and 294). Playford might be categorised as an exemplar of the latter, while there was undoubtedly elements of the former at play in Bjelke-Petersen's tilt for national power.

\section{The contemporary era compared}

How, then, do the contemporary sub-national leaders compare? The first point is that, unlike the 'boss' era premiers, they do not constitute a 'gerontocracy'. Since the 1980s there has been a general downward trend in the age at which premiers both obtained and left office. Whereas between the end of World War II and the 1970s the age of those elected as premier across the states averaged in their mid-fifties, that has since declined to the mid-forties. Correspondingly, the average age of exit from office has dropped even more sharply from around 62 to a little over 50. ${ }^{l}$ Allied with the trend of premiers becoming younger, the waiting time for office (as measured by the number of years between first entering Parliament and assuming the premiership) has decreased. Clune and Turner (2006: 5) note that during the twentieth century in New South Wales the waiting time for office peaked between 1941 and 1976 when it stretched out to over 23 years, while for the premiers from Neville Wran to Carr the period contracted to eight years. Similar patterns are evident in the other states with the waiting times in Victoria and Queensland, for example, almost halving since the 1980s. ${ }^{2}$ The changing age profile of sub-national leadership conforms to a phenomenon identified some two decades ago by Patrick Weller and Sue Fraser (1987) as the 'younging of Australian politics'. Not surprisingly, Weller and Fraser connected this trend to the changing career patterns of politicians, in particular that for a growing number of parliamentarians, politics was becoming a first rather than second career. Or, to put it another way, the 'younging' of politics (and leadership) can be linked to the growing prevalence of career politicians, those for whom 'their first careers (if they existed at all) were nothing but overtures to the main event' (Weller and Fraser 1987: 76).

Of the group of leaders analysed in Yes, Premier this is true at the very least of Beattie, Bracks, Carr and Rann. By the time they were 30 each of these future leaders had flagged an ambition to enter Parliament and/or was operating in a cognate occupation (for example, Beattie as state secretary of the Queensland Labor Party and Rann as press secretary to South Australian ALP leaders from Don Dunstan to John Bannon). Gallop was not far behind. He entered Parliament at age 34, following a brief academic career (Clune 2005; Costar and Hayward 2005; Manning 2005; Phillips and Black 2005; Wanna and Williams 2005a). The irony is that, as leaders, these career politicians were projected as ordinary men who happened to be political masters. Beattie even once likened himself to an 'anti-politician' (cited in Preston 2003: 406). Leaving that aside, the fact that their 'first' careers were in politics, coupled with the relative youth at which 
they assumed office, was undoubtedly a facilitating factor in their timely retirements.

These Premiers departed politics at an age when they still have the opportunity to construct a post-political career. Indeed, one might also speculate that the predisposition shown by 'ordinary populist' leaders for moving beyond politics is not only about a reversal of the traditional place occupied by politics in an individual's occupational history, but reflects a transformation of politics from being a craft (with its connotations of slowly acquired, abiding skills peculiar to that trade) to a career.

The expectations and demands associated with contemporary leadership at the sub-national level of politics appear also to have played a part in the recent spate of retirements. The notion of premiers being central to the operation of their governments and to the politics of their respective states has long been remarked upon. In his majestic mid-twentieth century study of Australian state governments, S. R. Davis (1960: 3) identified leadership predominance of premiers as an important ingredient in the longevity of many sub-national governments. Yet, the nature of that dominance has changed. Back then, for instance, Henry Bolte was known as the 'pepper and salt' premier because of his reputation for having a hand 'in everything' (cited in Bennett 1992: 144). It was a time when it remained possible for a premier to exercise personal and informal control over the machinery of government, and an era when it was still the norm for premiers to simultaneously hold the Treasury portfolio.

Fifty years on, the exponential growth in the complexity of government (just one measure of which is the rise in the number of ministerial portfolios) has diminished the capacity for premiers to single-handedly dominate government. Premiers are now compelled to delegate to ministers, and are required to operate within intricate and formalised administrative and accountability processes. They are also surrounded by complex and large support structures - over the past quarter of century or so premier's departments have expanded enormously in size as they have assumed greater co-ordinating functions, while the private offices of premiers have also grown dramatically (Clune and Turner 2006: 12-13; Halligan 1988). Shortly after Bracks' resignation, it was revealed that he had had about 70 staff, including around 20 political/policy advisers and 20 media advisers (Austin 2007).

The extraordinary number of media advisers in the Bracks office is a clue to the nature of leadership centrality twenty-first century style. While premiers can no longer operate as a one man band and the scope for ad hoc, informal decision-making has shrunk, their centrality to the performance (and image) of government has arguably never been greater. The template for what Wanna and Williams (2005: 15) describe as the 'the personalisation of leadership' at the sub-national level of politics is usually regarded as having been forged by Neville 
Wran, premier of New South Wales from 1976 to 1986. Indeed, it is striking how many of the features of state-level leadership described in Yes, Premier were road-tested during the Wran era. Not least of these were the embrace of modern media management techniques (with the leader centre stage to the government's media presentations); transcendence over the party's traditional base; and cautious pragmatism. As Graham Freudenberg (2006: 422) notes, Wran, having learnt from the Whitlam experiment, had an influence over all subsequent Labor administrations through his government's pragmatic balancing of both economic prudence and social progressivism; and anticipatory and receptive leadership. Wran, as well as being an adept 'crisis manager', took the previously rudimentary use of opinion polling by governments to new heights (Chaples, Nelson and Turner 1985: especially 247-50).

Yet, the Wran model was not without its hazards. Ernie Chaples, Helen Nelson and Ken Turner (1985: 250) argued:

... the Wran approach to leadership requires a very able politician, with much skill, energy, considerable insight, and probably more than a little luck. The 'man at the top' must operate continuously at peak efficiency ... the demands made by this style are constant and considerable, necessitating a leader who is in the best of form, both physically and emotionally.

Two decades on, those demands have only intensified in the context of the continuing expansion in the breadth and complexity of government. Coupled with this is the mutually reinforcing frenzied relationship that exists between governments engaged in permanent campaigning and constant news cycle management and a media of insatiable appetite. By contrast with the sedate political rhythms of earlier times, it is a climate in which high office is, as Peter Beattie has observed (2007), akin to 'being in the trenches of war', endlessly optimising the next advantage or warding off the next crisis. And, of course, it is leaders who are the chief gladiators in today's remorseless media-focussed political combat.

Do we find here another explanation for the recent run of leadership resignations? In other words, has a leadership model evolved that is unsustainable over the long haul - a model that has an in-built obsolescence date? In the extract from his diary that heads this chapter, Carr confessed to the gnawing anxiety that 'you can be wiped out by events, and within a 24 hours news cycle'. At the times of their resignations, Bracks and Beattie both alluded to the toll of the premiership. Bracks declared he had 'given everything, you know, body and soul, to this job', while his wife, Terry, reinforced the message, commenting: 'It's a relentless job. It's day in, day out. I've seen it first hand' (cited in Austin 2007a). Peter Beattie's wife, Heather, had also worried about the debilitating effects on her husband, complaining on the eve of his resignation that he was a 
'tired, exhausted man'. Beattie himself ventured that the increasing demands of the job might mean the time had come to consider imposing a sunset on the tenure of state premiers (Austin 2007a; Parnell 2007). It is Geoff Gallop, however, who has most thoughtfully articulated the wear and tear, both physical and psychological, of contemporary leadership. Not only are the stresses unremitting but, according to the former West Australian premier, the 'trick' performances that accompany high executive office and necessity of reducing complex issues to simple (media friendly) truths, have introduced an aridity, almost soullessness, to the task of modern leadership (Taylor 2006; Gallop 2006; 2007).

\section{Lessons for the federal sphere?}

As a procession of state leaders departed the political stage from mid-2005, John Howard chose a very different way to deal with political mortality. This turned out to be less a planned transition than a scorched earth strategy. As questions had grown more insistent about when he would abdicate the prime ministership as he passed his tenth anniversary in office in early 2006, Howard repeated ad nauseam the formula that he would remain leader as long as his party and the voters wanted him to stay. What Brett presciently detected as the 'disingenuousness in this promise' (2007: 10) was to be fully exposed during 2007 as the Coalition government slid inexorably towards electoral defeat. In September, spooked by a continuing succession of poor opinion polls, a majority of the cabinet conveyed to the prime minister that he ought to step aside for his long-time heir apparent Peter Costello, only to have Howard stare them down by making it clear that the party would have to blast him out of the leadership (Kelly 2007).

The end game came two months later at the November election, with the government heavily defeated and Howard losing his own seat. His jilted successor Costello, who subsequently maintained that Howard had never any intention of standing down voluntarily (Costello 2008), now had his own revenge of sorts by announcing that he would not seek the leadership of the severely depleted Liberal Party but would instead leave Parliament. In the words of one commentator, the defeated prime minister 'had incinerated two generations of Liberal leadership on the bonfire of his own vanity' (Milne 2007).

Walter and Strangio (2007: 13-16) have argued elsewhere that the extraordinary dominance exercised by Howard over his government carried the seeds for the Coalition shipwreck of 2007 and disarray on the non-Labor side of politics that has followed. The issue here, though, is less why Howard did not allow a transition, but whether things might be different in the future. In other words, could it be that future prime ministers heed Howard's mistake and seek to emulate the (recent) example of their sub-national counterparts by setting and abiding by a self-imposed de facto limit to their tenure? 
Notably, Howard's fate has spurred some soul-searching in the Liberal Party about these matters. In a recent speech to the federal Parliament, Victorian MHR Chris Pearce proposed 'a maximum of three parliamentary terms for any individual prime minister' (Pearce 2008). In doing so, Pearce aligned himself with Peter Beattie, who since political retirement has advocated US-style fixed terms for both prime ministers and premiers (see Berkovic 2007). Meanwhile, the former president of the Victorian Liberal Party, Michael Kroger, has urged his party to learn from the retirements of state Labor leaders about the importance of renewal of governments (Kroger 2008).

Indeed, there are instances where state leadership trends have influenced the federal sphere. For example, Don Dunstan's post-materialism was a path-setter for the Whitlam-led federal Labor Party, and Bob Hawke's leadership approach was undoubtedly influenced by the 'Wran model'. Moreover, if the recent bout of retirements at the sub-national level has something to do with the increasingly taxing nature of the role, then one would expect that imperative to be even more pronounced at the federal level where the demands of office are greater still. Already, doubts are being raised about the sustainability of the ferocious work rate of Howard conqueror Kevin Rudd and the toll that it is exacting on both him and his support staff (Hewett 2007; Murphy 2008).

However, a note of caution - there is a stark difference between sub-national and national leadership. In an era when globalisation and inexorable Canberra-driven centralism are eroding the scope for state autonomy, the gulf between sub-national and national politics is, if anything, widening. Whereas the 'boss' premiers were prone to regard themselves as near equals to the prime minister, today such a view is much harder to sustain. And as state politics becomes the domain for humbler ambitions, it might well be that it likely to produce political leaders more naturally disposed to relinquish office with less fuss. Federal politics, with its continuing seductions of expansive power (and immortality), is quite a different matter. When it comes to prime ministers, it might always be the case that, as Paul Keating has put it, '[they] have got Araldite on their pants ... They want to stick to their seat. And you either put the sword through them or let the people do it' (cited in Brett 2007).

\section{Final thoughts}

The sequence of leadership retirements at sub-national level since 2005 opens up further areas of inquiry. At the time of writing, the inheritors of leadership have in one case secured a further term in office (Iemma) or are riding comparatively high in public opinion polls. There is the prospect then for this group of leaders and their governments to be more than mere footnotes or epilogues to those that preceded them. Yet, a question remains about how much has actually been transformed as a consequence of change at the apex of executive government. Has the transition in leadership filtered down into changes in the 
supporting staff arrangements and into the system of public administration? Has the advent of a new leader precipitated significant policy renewal or have the changes been largely ephemeral - more about a different leadership style than substance? To approach this from another direction: how much does a leadership successor remain captive to the agenda and governing apparatus bequeathed by his/her predecessor? Are the opportunities for a distinctive leadership project and the personalisation of the political executive diminished for successors?

Underlying all this is the fundamental question of how much renewal a leadership transition actually delivers. When Beattie retired he packaged the decision as essential to renewal of the Labor government - 'parties that renew, survive' (Parnell 2007), he declared - and his resignation was, by and large, accepted (and welcomed) in that light. Conversely, as suggested above, Howard's failure to stand aside has been identified as a key reason for the federal Coalition government running out of puff by its fourth term. By this light, leadership transition and renewal are deemed virtually synonymous, with the former a prerequisite for the latter. A study of the current sub-national Labor governments and their second generation leaderships would be an ideal place to investigate whether these assumptions stand up.

\section{References}

Abjorensen, N., 2007, Leadership and the Liberal Revival: Bolte, Askin and the Post-War Ascendancy, Melbourne: Australian Scholarly Publishing.

Austin, P., 2007, 'Taxpayers pick up the bill for hundreds of advisers', The Age, 10 September.

Austin, P., 2007a, 'One eight-year plan that Brumby would do well to adapt', The Age, 1 November.

Beattie, P., 2007, 'Calmed after the storms', Weekend Australian, 10-11 November.

Bennett, S., 1992, Affairs of State: Politics in the Australian States and Territories, Sydney: Allen \& Unwin.

Berkovic, N., 2007, 'We need fixed terms: Beattie', The Australian, 13 December.

Blewett, N. and D. Jaensch, 1971, Playford to Dunstan: The Politics of Transition, Melbourne: F. W. Cheshire.

Bolton, G., 1992, Spoils and Spoilers: A History of Australians Shaping their Environment, Sydney: Allen \& Unwin.

Brett, J., 2007, 'The Nation Reviewed', The Monthly, 21, pp. 10-14.

Chaples, E., H. Nelson and K. Tuner, 1985, 'The Wran model in perspective', in E. Chaples, H. Nelson and K. Turner (eds), The Wran Model: Electoral 
Politics in New South Wales 1981 and 1985, Melbourne: Oxford University Press.

Clune, D., 2005, 'Bob Carr: The unexpected Colossus', in J. Wanna and P. Williams (eds), Yes, Premier: Labor Leadership in Australia's States and Territories, Sydney: UNSW Press.

Cockburn, S., 1991, Playford: Benevolent Dictator, Adelaide: Axiom.

Costar, B. and D. Hayward, 2005, 'Steve Bracks: Victoria's "nice guy" who won against the odds', in J. Wanna and P. Williams (eds), Yes, Premier: Labor Leadership in Australia's States and Territories, Sydney: UNSW Press.

Davis, S., 1960, The Government of the Australian States, London: Longmans.

Freudenberg, G., 2006, 'Neville Kenneth Wran', in D. Clune and K. Turner (eds), The Premiers of New South Wales, volume 2, 1901-2005, Sydney: The Federation Press.

Galligan, B. and W. Roberts (eds), 2007, The Oxford Companion to Australian Politics, Melbourne: Oxford University Press.

Gallop, G., 2006, interviewed by M. McKew, 'Geoff Gallop: From darkness into light', Sunday Profile, ABC Radio, 17 September, <http://www.abc.net.au/cgi-bin/common/printfriendly.pl? http://www.abc.net.au/sunday>

Gallop, G., 2007 interviewed by T. Jones, ‘Gallop discusses media's election ambushes', Lateline, ABC Television, 1 November, $<$ http://www.abc.net.au/lateline/content/2007/s2079416.htm>

Halligan, J., 1988, 'State Executives', in B. Galligan (ed.) Comparative State Policies, Melbourne: Longman Cheshire.

Hannan, T., 1979, 'Electoral and parliamentary patterns in Victorian politics, 1945-76', in P. Hay, I. Ward and J. Warhurst (eds), Anatomy of an Election, Melbourne: Hill of Content.

Head, B, J. Wanna and P. Williams, 2005, 'Leaders and the leadership challenge', in J. Wanna and P. Williams (eds), Yes, Premier: Labor Leadership in Australia's States and Territories, Sydney: UNSW Press.

Hewett, J., 2007, 'No yawning folks, it's time for work, says Kevin 24/7', Weekend Australian, 15-16 December.

Kelly, P., 2007, 'The Defeat', Weekend Australian, 15-16 December.

Knight, K., 2003, 'Edward Michael Hanlon: A City Bushman', in D. Murphy, R. Joyce, M. Cribb and R. Wear (eds), The Premiers of Queensland, St Lucia: University of Queensland Press. 
Kroger, M., 2008, 'Liberals should focus on branch renewal', The Australian, 19 February.

Manning, H., 2005, 'Mike Rann: A fortunate "king of spin"”', in J. Wanna and P. Williams (eds), Yes, Premier: Labor Leadership in Australia's States and Territories, Sydney: UNSW Press.

McIntyre, A., 1988, 'Conclusion', in A. McIntyre (ed.) Aging and Political Leadership, Melbourne: Oxford University Press.

Milne, G., 2007, 'PM's hubris leaves the Liberal Party in ruins', The Australian, 26 November.

Murphy, D., R. Joyce, M. Cribb and R. Wear (eds)., 2003, The Premiers of Queensland, University of Queensland Press, St Lucia.

Murphy, K., 2008, 'Rudd's will to power', The Age, 29 March.

Parnell, S., 2007, 'Peter Beattie resigns from politics', The Australian, 10 September.

Pearce, C., 2008, Governor-General's Speech: Address-in-reply, http://parlinfoweb.aph.gov.au/piweb/view_document.aspx?id=2788877 $\&$ table $=$ HANSARDR, accessed 21 February.

Phillips, H. and D. Black, 2005, 'Geoff Gallop: A new generation Labor man', in J. Wanna and P. Williams (eds), Yes, Premier: Labor Leadership in Australia's States and Territories, Sydney: UNSW Press.

Preston, N., 2003, 'Peter Douglas Beattie: The Inclusive Populist', in D. Murphy, R. Joyce, M. Cribb and R. Wear (eds), The Premiers of Queensland, St Lucia: University of Queensland Press.

Richards, M., 2002, The Hanged Man: The Life and Death of Ronald Ryan, Melbourne: Scribe.

Smith, R., 2006, 'Robert John Carr', in D. Clune and K. Turner (eds), The Premiers of New South Wales, volume 2, 1901-2005, Sydney: The Federation Press.

Strangio, P. and B. Costar (eds)., 2006, The Victorian Premiers, 1856-2006, Sydney: The Federation Press.

Strangio, P., 2006, 'John Cain jnr: The burden of history', in P. Strangio and B. Costar (eds), The Victorian Premiers, 1856-2006, Sydney: The Federation Press.

Taylor, P., 2006, 'Political life so shallow, says Gallop', The Australian, 10 June 2006.

Walter, J. and P. Strangio, 2007, No, Prime Minister: Reclaiming Politics from Leaders, Sydney: UNSW Press. 
Walter, J., 2003, 'Johannes Bjelke-Petersen: "The Populist Autocrat"', in D. Murphy, R. Joyce, M. Cribb and R. Wear (eds), The Premiers of Queensland, St Lucia: University of Queensland Press.

Wanna, J. and P. Williams, 2005a, 'Peter Beattie: The "boy form Atherton" made good', in J. Wanna and P. Williams (eds), Yes, Premier: Labor Leadership in Australia's States and Territories, Sydney: UNSW Press.

Wanna, J. and P. Williams, 2005, 'The Twilight Zone of State Leaders', in J. Wanna and P. Williams (eds), Yes, Premier: Labor Leadership in Australia's States and Territories, Sydney: UNSW Press.

Wanna, J., 2003, 'Wayne Keith Goss: The Rise and Fall of a Meticulous Controller', in D. Murphy, R. Joyce, M. Cribb and R. Wear (eds), The Premiers of Queensland, St Lucia: University of Queensland Press.

Weller, P. and S. Fraser, 1987, 'The Younging of Australian Politics or Politics as First Career', Politics, 22:2, pp. 76-83.

Whitlam, G., 1985, The Whitlam Government, 1972-1975, Melbourne: Penguin.

Wright, R., 1992, A People's Counsel: A History of the Parliament of Victoria 1856-1990, Melbourne: Oxford University Press.

\section{ENDNOTES}

\footnotetext{
1 The author's calculations based on data found in the appendices on state premiers in Galligan and Roberts (2007: 654-5 and 658-66).

2 The author's calculations based on information in the relevant chapters in Murphy et al. (2003); and Strangio and Costar (2006).
} 